\title{
Artistic Portrayal of Death as a Refuge from Morbidity: The Pillowman by Martin McDonagh and 4.48 Psychosis by Sarah Kane
}

\author{
Sobia Kiran ${ }^{1}$ \\ ${ }^{1}$ MA English Student, Department of English, York University, Toronto, Canada \\ Correspondence: Sobia Kiran, Department of English, York University, Toronto, Canada. E-mail: \\ sobiakiran@yahoo.com
}

Received: February 7, 2017 Accepted: February 25, 2017 Online Published: February 28, 2017

doi:10.5539/ells.v7n1p101 URL: http://doi.org/10.5539/ells.v7n1p101

\begin{abstract}
The Pillowman by Martin McDonagh and 4.48 Psychosis by Sarah Kane are psychological plays that deal with the relationship between Art, Death and Morbidity. Death is an artistic solution to put an end to the morbidity of attitude caused by toxic relationships, social conventions, and totalitarian institutions. Death, may it take form of suicide or murder, is presented as a Saviour to escape the torture, suffering, depression and tyranny. Art is the creative realm of death, a defensive tool or a protective shield against the repressed uneasy traumatic memories that causes extreme unpleasure. The objective of the paper is to explore the artistic portrayal of death as a refuge from morbidity addressing the research questions 1) How do 4.48 Psychosis by Sarah Kane and The Pillowman by Martin McDonagh suggest death as an escape from psychosis and life of suffering? 2) How does art become a source of realization of Death drive taking form of murder or suicide?
\end{abstract}

Keywords: death, morbidity, Thanatos, repression, art

\section{Introduction}

Sigmund Freud presents the idea of Thanatos or Death Drive and says that there is "opposition" between "ego or death instincts" and "sexual or life instincts" (Freud, 1950, p. 38). There is a dominant obsession with death, "...that everything living dies for internal reasons - becomes inorganic once again - then we shall be compelled to say that "the aim of all life is death"..." (p. 32) Thanatos or Death Drive results in either sadism which gives pleasure by destroying or killing others or masochism that gives pleasure in killing or destroying one's own self. He refers to Schopenhauer's philosophy, "For him death is the "true result and to that extent the purpose of life"..." (p. 44). Thanatos or Death drive emerges from repressed instincts in the unconscious. Loss or trauma does not necessarily take the form of melancholia. Whenever the protective shield of conscious due to some trauma gets weak, these repressed feelings emerge and take the form of Thanatos releasing energy in a sadistic or masochistic way. The purpose is again to escape the unpleasure caused by repressed instincts. Death drive thus generates a certain kind of ambiguity, for it is destructive but realized with the purpose to avoid unpleasure. Thanatos or Death drive runs as a dominant theme in The Pillowman by Martin McDonagh and 4.48 Psychosis by Sarah Kane. In both plays, the characters try to escape their morbid state of mind because they are haunted by their repressed past. Morbidity appears in the form of psychosis, dysphoria, retarded mind and even stories. The bitterness of their existential experience has made them sadist and masochist but with a twist that death does not appear as a cruel act of violence rather it emerges as a shelter and refuge from the constant misery of life.

The Pillowman by Martin McDonagh and 4.48 Psychosis by Sarah Kane are psychological plays that deal with the relationship between Art, Death and Morbidity. Death is an artistic solution to put an end to the morbidity caused by depression, toxic relationships, social conventions, and totalitarian institutions. Death, may it take the form of suicide or murder, is presented as a Saviour to escape the torture, suffering, depression and tyranny. Art is the creative realm of death, a defensive tool or a protective shield against the repressed uneasy traumatic memories that cause extreme displeasure. The objective of the paper is to explore the artistic portrayal of death as a refuge from morbidity addressing the research questions 1) How do 4.48 Psychosis by Sarah Kane and The Pillowman by Martin McDonagh suggest death as an escape from psychosis and life of suffering? 2) How does art become a source of realization of Death drive taking the form of murder or suicide? 


\section{Discussion}

Lyn Gardner in her review in The Guardian writes, "Posthumously produced at the Royal Court in London in 2000, 18 months after the playwright's death, 4.48 Psychosis presents intriguing difficulties and possibilities. How do you perform a blank page? A series of numbers? A piece that is ambivalent about gender and character? A script that has too often been seen as a theatrical suicide note?" (Gardner, 2015) Elisabeth Vincentelli in her review in New York Post writes, "one-act piece is a bleak, nihilistic exploration of the mind of a woman about to commit suicide - as Kane herself did, in 1999. She was 28." (Vicentelli, 2014) Aleks Sierz compares her suicide to the suicide of Sylvia Plath. "The case of Sarah Kane, the 28-year-old playwright who hanged herself on 20 February 1999, inevitably recalls Plath. Once again, here was a precocious but self-destructive young talent whose death changed the way we look at her work." (Sierz) Saunders is right to comment in his book Love Me, or Kill Me. Sarah Kane and the Theatre of Extremes, that the cause of her depression was "the hopeless perspective of human existence." He further says, "Unsuccessfully, she looked for a solution in life and in art. Her depression was also existentially anchored in hopelessly cruel world." (Saunders, 2002)

The protagonist of the play suffers from pathological grief with her mood fluctuating from "fucking angry" to "very angry" (Kane, 2000, p. 17). She is suffering from dysphoria. She feels "to be born in the wrong body" (p. 10). She is leading a lonely life without love and warmth. She feels rejected by her lover, tortured and tormented by her father, neglected by her mother and frustrated by her love for the "absent". She is sick of the morbid life she is living. She feels being punished by existence through her utter incapacity to have normal relations with others. Her diseased body has become a burden for her. Her morbid mental condition has failed her to see the objective reality and made her a laughing stock for others. The protective shield of her conscious has given way to Thanatos taking the masochistic twist in her decision to hang herself to avoid the further agony offered by existence. "At 4.48 when depression visits I shall hang myself." (p. 4) This is a well thought out decision to escape depression that she translates as anger.

Providing justification for her decision, she gives vent to her anger over all the frustrations she faced in dealing with life, mental health treatment and human relationships. All medical prescriptions and kind words are a "masquerade" for her. To her the whole idea of psychotherapy and mental treatment through medication and counselling is ridiculous. The procedure is carried out without the least personal or emotional involvement. For her, all sympathetic and kind words are lies for they are performed not to please her but to medically cure her. She may feel humiliated, ashamed or horrified, the world does not care. She is confined in a room of "expressionless faces" (p. 5). The love she feels, the physical desire she experiences is left unanswered. "And I cannot believe that I can feel this for you and you feel nothing. Do you feel nothing?" (p. 9) She feels "manipulated". Her attempts to be seen or heard and to get attention fail. Her wish to regain her self-respect by overcoming her sense of humiliation ends in vain. This cold behaviour is responsible for her morbid attitude. She is informed that her morbid state of mind and body is not her fault so many times that she feels guilty conscious.

Lacan says that the self develops in the locus of the other. Self wants to be recognized by others in order to exist. She also wants to return to the normal routine of life, her cathexis for the doctor is her initial belief that the treatment will enable her, to form mutually enjoyable, enduring, cooperating and reciprocating relationship with Other, with an equal to be forgiven to be loved to be free" (p. 25).

Only love and care can cure her which the professional medical system fails to offer. Her death is a sort of sacrifice offered in the name of love to register her need for care and to be known. "See me Love me" (p. 31). Her plea is unanswered. She feels betrayed by her life, so she turns to death.

Only death can provide her respite from her morbid mind. She thinks of the options open to her. "Take an overdose, slash my wrists then hang myself." (p. 7) Her sexual desire has taken the form of Thanatos "death drive resulting in masochism and sadism. She hurts her body and that makes her feel great. She has a tendency to cut her limbs," gouge her eyes and shave her head. She has suicidal desires and is haunted by homicidal thoughts "towards several doctors and drug manufacturers" (p. 17). "Everything passes Everything perishes" (p. 12), so does emerge the towering desire to return to one's roots, to die. Only death can release her pain, her tension and anger. Only death can rescue her from a bleak hopeless world. Her alliteration of "No Hope" sums it all. Death is the final reality, then why not to willingly embrace it herself. Death has the power to free her from the cage of existence full of "doubt", "despair" and "horror" (p. 13) Death provides her a choice, an option, an opportunity which life denies. "Nothing is forever." (p. 20)

Life cannot be enjoyed beyond human limitations. Only death has the power to liberate man. Only through death can he achieve freedom. Death emerges out of the play, a piece of Art. Death's offer of freedom is common with Art. For her art is literary "kleptomania" a "holy act" of theft. (p. 9) Expression or style make a word a piece of 
art. It is art that is going to create drama but also record her suicide note. The expression renders this note into a piece of art. Death emerges from this literary piece and provides the end note to the life of the artist. Life is a "repugnant tale" that approaches its end with the pen of the artist. It has the power to create death to free the soul from the morbid body that is already a "carcass". It has the power to unfold the tale of existence and then to drop the curtains announcing the final scene.

The Pillowman also makes us explore the morbid minds of the characters entrapped in the web of existence. In Psychosis, it was doctors, in this play, there are cops and parents causing so much unpleasure that the result is Thanatos taking the form of sadism and masochism. The characters live in a dictatorial world divided between sufferers and tormentors, where the weak have no rights. "You've got no fucking rights...." (McDonagh, 2003, p. 20) As victims of toxic relationships and suffering the resultant morbid state of mind (Michael) or state of Art (Katurian) they find escape through death that this time too emerges from the creative realm of Art/literature. Brian Cliff, in his article "The Pillowman: A new story to tell", talks about the two important themes of the play, of "the artist in a totalitarian state" and of "the broader connections between artist and suffering", myth of "the artist made great by his suffering and the myth of the suffering created by his violent art." (Russel, 2017, p. 136)

Katurian writes stories, in which death appears as a Saviour both to save the victims from the life of misery and to stop the perpetrators of violence to continue their cruelty. The stories depict the people suffering without any reason. The innocent children suffer the tyranny of the adult world because they cannot defend themselves. Here death appears as a sort of crucifixion in a cruel world. The little Jesus girl receives beating for every good deed. Her love and kindness did not work in a world full of hatred. May it be the man in the gibbet who is not informed of sin or the little girl who thinks herself to be Christ, they suffer the hatred and persecution just as Christ did despite his love and kindness.

Storytelling takes a hideous obsession. It takes diabolic power to shape reality. Hurley writes in his review of the play;

...it is equally a tale about the act of storytelling itself. Throughout the play the importance of storytelling is reinforced, especially by Katurian, who expresses this early on when he tells detective Tupolski, "the first duty of a storyteller is to tell a story and I believe in that wholeheartedly." ("Hurley: The Pillowman Review")

The Guardian also highlights this aspect of the play. "McDonagh's subject is clear: the dangerous power of literature.... Katurian is so convinced of the sanctity of literature that he will do anything, even confess to crimes he has not committed, to save his stories: no internal doubt means no drama." (Billington, 2003)

Michael's morbid state of mind is the result of years of torture and abuse by his own parents who carried out an experiment to polish the artistic skills of Katurian, a creative genius. Parents' diseased attitude is apparent in their love showered on one son in contrast to their torture directed to the other son. In the beginning, Katurian writes happy stories, "short stories, fairy tales, little novels, all happy, colourful things" (McDonagh, 2003, p. 23), but later he starts producing morbid pieces of writing as a result of exposure to screams of his tortured brother. His questions about screams are repressed by his parents making his imagination responsible for them. He receives another trauma on the day he receives his writing award when a note in blood is slipped inside his room." They have loved you and tortured me for seven straight years." (p. 22) This was also an experimental drama staged by his parents. It is the dark experimentation of the parents to polish his artistic skills that ends in making his stories grow “darker and darker". (p. 23)

In one of his stories, appears the character of pillowman, made of nothing but pillows, "Well, the Pillowman had to look like this, he had to look soft and safe, because of his job, because his job was a very sad and a very difficult one..." (p. 30) The traumatic experiments make him a psychotic who develops a split personality. He considers his parents responsible for the morbid mental condition of his elder brother whose brain is damaged beyond cure. He kills his parents to save his brother from torture. Katurian performs the character of pillowman while killing his parents thus avoiding unnecessary pain or torture, bringing upon a soft death with no scars, no wounds and no visible abnormalities. Death appears as a tool of protection for a weak and helpless sibling from the cruel clutches of oppressors (parents). It is an artistic response to end violence by taking the life of the victimizer or by convincing the victims to take their own life. It is an act of compassion, an act of humanism.

Pillowman would go back in time to when that man or that lady was just a little boy or a little girl, to when the life of horror they were to lead hadn't quite yet be gun, and the Pillowman's job was very very sad, because the Pillowman's job was to get that child to kill themselves, and so avoid the years of pain that would just end up in the same place for them anyway. (p. 31) 
Death like Art is a mode to control life, to shape the destiny. Art has the power to recreate and reshape life by highlighting its selected shades and by controlling the plot of the story. Art has the power to create and the paramount feature of human existence i.e., death. It has the power to transcend the barriers set by time, travel back and forth to make changes in the course of life, by putting an end to it in the beginning to end a long journey of unhappiness. Art has the power to suspend disbelief and to transfer the reader into another world and death too shares this power to break the shackles of this existence. Minutes before the execution, Katurian plays the pillow man once more to save Michael a painful death from execution and is ready to suffer the death alone. "Sweet dreams, little baby. I'll be coming along soon". (p. 46) Death is suggested as an extreme and absolute solution to the unbearable problems of the world.

Death and Art both provide the opportunity to exercise human will and thus to enjoy some self-significance. Death and Art can make life meaningful by empowering man to decide for himself. Death and Art have the power to control human behaviour and thus changing the course of the destiny. Pillowman emerges as a Messiah to save the children from the miserable life they are supposed to live. Such is the power of Art that Michael feels compelled to carry out the stories. Art connects them psychologically. His cathexis for the character of pillowman is so powerful that he enacts it in the real life thus exercising Thanatos to give vent to his repressed childhood memories.

See, when the Pillowman was successful in his work, a little child would die horrifically. And when the Pillowman was unsuccessful, a little child would have a horrific life, grow into an adult who'd also have a horrific life, and then die horrifically. (p. 32)

A horrific death is used as a defence against the horrific experience of "shitty" life. "all he ever wanted to do was to be able to help people," (p. 32). He travels back to his own past and makes the little pillow boy burn himself to death again out of compassion. He dies with a smile on his face, a smile of relief to be free from the life-long misery of carrying out his sad job. "The last thing he heard was the screams of the hundred thousand children he'd helped to commit suicide coming back to life and going on to lead the cold, wretched lives that were destined to them because he hadn't been around to prevent them..." (p. 33). They lost their saviour from misery, their companion to set them free from the gibbet of existence. They were left to suffer and die alone.

Art has the power to suspend disbelief and to transfer the reader into another world and death too shares this power to break the shackles of this existence. Art becomes performative, a call, a command to Michael, "You know. Because you told me to." (p. 34) and he tried doing the stories.The pillowman in the story emerges as a hero, so Michael identifies himself with him, "And he's the hero! And I'm not criticising. He's a very good character. He's a very very good character. He reminds me a lot of me." (p. 36) He is convinced of a horrible life awaiting every child because of his and Katurian's bitter childhood. Thus, he plays the role of pillowman "a thoughtful decent man". (p. 36)

While waiting for execution, Katurian comments, "There are no happy endings in real life." (p. 41) Katurian's murder of his parents to save his brother only ended in the murder of innocent children by Michael and execution of both brothers. For Tupolski too, "I think the world's a pile of shit." (p. 57) Even he finds something "gentle" about the pillowman. Ariel also is troubled by his repressed uneasy childhood that makes him behave in a violent way despite his sympathies for Katurian and his stories that are an artistic representation of Thanatos. He also killed his father who sexually abused him when he was only eight. Katurian gets shot but his stories are saved by Ariel to be re-explored after fifty years of Katurian's execution. Thus, death also emerges as a saviour for art in the form of stories. The cycle is complete as in the first it was art from where the death drive or Thanatos emerged.

\section{Conclusion}

In brief, both The Pillowman and 4.48 Psychosis draw our attention to a bleak dark world where life is like a gibbet, a cage and the only way out is death. Death becomes a defence mechanism against the misery and torment caused by oppressors. It provides a refuge from morbidity caused by psychosis, toxic relations and very human existence. The world depicted in both plays is an insensitive cruel world that does not care for the individuals, a world where compassion and kindness do not exist, where personal affiliation is given up for the sake of mechanical professionalism. May it be doctors or cops, they carry out their duty without a human feeling or personal involvement. Cops, parents and doctors represent the oppressive administrators who enjoy all the privileges, providing others no rights. Living above the law, they become the law, while others have to obey as good objects. Their oppression results in the morbid state of mind of the characters in both plays. Only death emerging from the realm of Art offers them freedom from their morbidity. 


\section{References}

Ashley, T. (2016). 4:48 Psychosis Review. The Guardian. Retrieved from https://www.theguardian.com/music/2016/may/25/448-psychosis-review-sarah-kane-philip-venables-opera

Billington, M. (2003). The Pillowman. The Guardian. Retrieved from https://www.theguardian.com/stage/2003/nov/14/theatre

Brantley, B. (2015). A Storytelling Instinct Revels in Horror's Fun. The New York Times. Retrieved from http://www.nytimes.com/2005/04/11/theater/reviews/a-storytelling-instinct-revels-in-horrors-fun.html?_r=0

Crawley, P. (2015). Review: The Pillowman. The Irish Times. Retrieved from http://www.irishtimes.com/culture/stage/review-the-pillowman-1.2124771

Frued, S. (1950). Beyond the Pleasure Principle. Translated by James Strachey. New York: Liveright Publ-ishing Corporation.

Gardner, L. (2015). 4:48 Psychosis Review: painfully funny revival of Sarah Kane's last work. The Guardian. Retrieved from https://www.theguardian.com/stage/2015/mar/15/448-psychosis-sheffield-crucible-review

Kane, S. (2000). 4.48 Psychosis. Royal Court Jerwood Theatre Upstairs, London. Retrieved from $\mathrm{http} / /$ rlmalvin.angelfire.com/KaneSarah448Psychosis.pdf

Lacan, J. (2004). Four Fundamental Concepts of Psycho-Analysis. London, GB: Karnac Books. Retrieved from ProQuest ebrary. Web. 6 December 2016.

McDonagh, M. (2003). The Pillowman. New York: Dramatists Play Service Inc.

Russell, R. R. (2007). Martin McDonagh: A Casebook. London, New York: Routledge.

Saunders, G. (2002). "Love Me Or Kill Me”: Sarah Kane and the Theatre of Extremes. Man Chester: University Press.

Sierz, A. (n. d.). Sarah Kane 2. Retrieved from http://www.inyerfacetheatre.com/archive7.html\#b

Vincentelli, E. (2014). Suicide Play “4:48 Psychosis” Offers a Cliché Mind Trip. New York Post. Retrieved from http://nypost.com/2014/10/20/suicide-play-448-psychosis-offers-a-cliche-mind-trip/

\section{Copyrights}

Copyright for this article is retained by the author(s), with first publication rights granted to the journal.

This is an open-access article distributed under the terms and conditions of the Creative Commons Attribution license (http://creativecommons.org/licenses/by/4.0/). 